\section{Windscale go-ahead; waste committee set up}

British Nuclear Fuels Limited have won the final stage in their battle to build a $£ 600 \mathrm{~m}$ expanded nuclear fuel reprocessing plant in North-West England. On Monday the House of Commons gave its approval, by a vote of 224 to 80 , to the instrument which gives BNFL the right to begin building a thermal oxide reprocessing plant (THORP) capable of handling 1,200 tonnes per year of oxide fuel. BNFL's first step will be to construct cooling ponds for incoming fuel rods, and to make a detailed design of the plant. The first bricks of THORP will not be laid for perhaps as long as 5 years, and the plant will not be operational until the 1990s.

This gap was noted by a number of MPs. Mr Michael Heseltine, opposition spokesman on the issue, said "This is not an irreversible decision... this house should have a final opportunity to look at the facts after 3 or 4 years have passed". The opposition supported the present order but the house "should be kept informed".

Peter Shore, Secretary of State for the Environment, appeared to agree. $\mathrm{He}$ announced the setting up of a "radioactive waste management committee" (as recommended by the Flowers Commission on Environmental Pollution some years previously). The committee will report annually to the House. It will be chaired by Sir Denys Wilkinson, Vice-Chancellor of the University of Sussex and ex-head of the Depantment of Nuclear Physics at Oxford. Members of the committee have not yet been named but they will contain "a majority of nine or ten independent people with expertise in the relevant areas," said Mr Shore. There will also be representatives of BNFL, the United Kingdom Atomic Energy Authority, the electricity generating boards, and trade unions.

Such are the vagaries of parliamentary procedure that Nigel Forman, one of the best-informed Tory MPs on energy matters, was given little chance to speak in the debate. The house has thus left unheard a strong criticism of the economics of THORP. As the principal argument for THORP to be heard in the House was that it had enormous economic value to Britain, the loss of Forman's speech was significant. Robin Cook based his criticism on the inadequacies of the Parker report, which he doubted would stand the test of the next 3 or 4 years, and on proliferation, which he insisted THORP would increase by its example. "If we have a reprocessing plant, how can we object to Brazil or Pakistan having one too?" Robert Walgate

\title{
NIH may loosen recombinant DNA research guidelines
}

MAJor changes are expected to be announced soon in both the administration and the content of guidelines established by the National Institutes of Health for the conduct of research using recombinant DNA techniques.

The existing guidelines were laid down in 1976, and a draft of proposed revisions was published last summer by the director of NIH, Dr Donald Fredrickson, following evidence which, according to many observers, showed the guidelines to be overrestrictive.

Dr Fredrickson is now about to publish a further version of the proposed revision, with in many cases even lower safety requirements than suggested last year. This follows the acceptance of a number of recommendations put by Dr Fredrickson to the NIH's Recombinant DNA Mole. cule Programme Advisory Committee, which was responsible for drawing up the original version of the guidelines.

One important recommendation is that responsibility for the safe conduct of research using recombinant DNA techniques should be devolved from the NIH to the research institutions themselves, where it would be the responsibility of an institutional biohazard committee.

Such a committee would be empowered to approve the safety precautions proposed for a particular experiment. Rather than the research worker requiring to have a Memorandum of Understanding and Agreement accepted by the NIH, it will merely be necessary for the biohazards committee to provide notification that an experiment has been approved, and to file the MUA with the NIH.

In view of their greatly increased responsibility, the biohazards committees would include members of the public. (In a close vote, the advisory committee also suggested that employees' representatives should be included, but Dr Fredrickson has not yet indicated whether he is prepared to accept this.)

With regard to the content of the guidelines, the advisory committee accepted a recommendation from $\mathrm{Dr}$ Fredrickson to allow a substantial reduction in the safety requirements necessary to conduct work involving viruses.

This recommendation was based on the conclusions of a working party which met at NIH last month, as well as an EMBO workshop held in England last year. Containment levels for cloning viruses from warm-blooded vertebrates in Escherichia coli, for ex- ample, would be reduced to the P2/EK1 combination of physical and biological containment; the existing proposal is to revise the level down to P4/EK1 or P3/EK2.

The advisory committee also approved the exemption from the guidelines of research involving certain recombinant DNA molecules which consist entirely of plasmid sequences from species that exchange DNA by known physiological processes, even though one or more of the segments may be a synthetic equivalent.

The committee approved for exemption a number of such experiments, making the exception of research involving Bacteroides sp. and Haemophilus influenzae.

In making his recommendations to the advisory committee, Dr Fredrickson emphasised the desirability of agreeing on alterations before the passage of legislation extending the guidelines to all research carried out using recombinant DNA techniques, including that in private industry.

However, on Capitol Hill the chances of legislation being passed within the near future are becoming increasingly remote. The House of Representatives has not set a date to debate HR11192, the bill reported out of $\mathrm{Mr}$ Harley Staggers' commerce committee over two months ago; and in the Senate there is still confusion about what the next step will be.

Senator Edward Kennedy, chairman of the health and scientific research subcommittee of the human resources committee, who had previously introduced his own version of the House bill, is now reported to feel that no new federal legislation may be necessary after all. Two weeks ago Kennedy wrote to Dr Joseph Califano, Secretary for Health, Education and Welfare, asking whether existing legislationsuch as Section 361 of the Public Health Service Act which gives Califano control over protection against "communicable diseases"-may provide adequate legislative machinery.

The HEW has replied to Kennedy, however, that the administration is still keen to see the implementation of HR 11192, and that it does not consider Section 361, which contains no provision for federal preemption of state controls, to represent "appropriate authority" for achieving uniform regulation of recombinant DNA research. There is also uncertainty within the administration over whether the potential dangers can be classified as a communicable disease.

David Dickson 